\title{
Relationship of breast fillet deboning time to shear force, pH, cooking loss and color in broilers stunned by high electrical current
}

\author{
Petri A. Papinaho \\ Department of Food Technology, University of Helsinki, Finland \\ Daniel L. Fletcher \\ Department of Poultry Science, University of Georgia, USA \\ Hannu J. Rita \\ Department of Forest Resource Planning, University of Helsinki, Finland
}

\begin{abstract}
Experiments were conducted to determine the relationships between deboning time and broiler breast meat quality, as determined by objective meat tenderness, $\mathrm{pH}$, color and cooking loss. All birds were processed in a European commercial processing plant using a high current, constant voltage stunning system and air chilling. According to a modified Mitscherlich response equation, $\mathrm{pH}$ values reached their ultimate value by $5.77 \mathrm{~h}$ post-mortem, with an asymptotic $95 \%$ confidence interval of $5.72 \mathrm{~h}-$ $5.81 \mathrm{~h}$ post-mortem. The shear force data, which were analyzed using a logistic model, suggested that broiler breast fillets should be aged intact on the carcass for $10.58 \mathrm{~h}, 5.94 \mathrm{~h}$ or $2.28 \mathrm{~h}$ to guarantee that over $95 \%$ of the fillets reach Allo-Kramer shear forces of $8.0,9.0$ or $11.0 \mathrm{~kg} / \mathrm{g}$, respectively. Since acceptable meat tenderness values vary with country, geographical area, or consumer groups, acceptable ranges should be determined according to potential market demands. No relationships between deboning time and fresh meat color or cooking loss was found.
\end{abstract}

Key words: breast muscle, tenderness, modeling

\section{Introduction}

In Europe, a growing proportion of fresh broiler breast meat is marketed to consumers as a boneless product. Often the breast meat is mechanically deboned immediately after air chilling, within $60-90$ minutes post-mortem. There have been numerous published studies, mostly in North America, showing that longer aging times between slaughter and deboning are required to produce tender meat (Pool et al. 1959, Dodge and Stadelman 1959, Stewart et al. 1984, Lyon et al. 1985, Sams and Janky 1986, Daw- 


\section{AGRICULTURAL AND FOOD SCIENCE IN FINLAND}

\section{Papinaho, P.A. et.al.: Broiler breast fillet deboning time and quality}

son et al. 1987, Sams et al. 1989). Recommendations have been made to age intact broiler carcasses for at least 4 to 6 hours post-mortem prior to removal of the breast muscles (Goodwin 1984, Shelton 1985, Stadelman et al. 1988). These recommendations are primarily based on research and practical experiences from processing lines using non-standardized low voltage (and low current) stunners, and rapid ice and water immersion chilling; methods not commonly used in the Western European poultry industry. Early deboning of poultry meat has been reported to have some advantages as well as disadvantages. Early deboned broiler breast meat can be suitable for formulating into processed rolls (Boyd and Ball 1973). Also, sausages made from hot boned thigh meat have been reported to have a higher emulsion capacity, but a greater cooking loss than samples made from cold deboned, aged meat (Lyon et al. 1983).

Little has been published concerning the deboning time as related to broiler meat tenderness, color, and cooking loss, using European high current stunning and air chilling. Also, experiments conducted in commercial processing plants have been rarely published.

The objective of this study was to determine the relationship between deboning time and broiler breast meat quality in a European commercial processing plant using high current stunning and air chilling. Breast meat quality was determined using objective meat tenderness, $\mathrm{pH}$, color and cooking loss.

\section{Material and methods}

Three trials, with 56 birds in each, were conducted using mixed sex, 37-day-old Ross 208 broilers. Feed was removed from the birds at 8 $10 \mathrm{~h}$ before slaughter, but birds were allowed free access to water. The birds were caught and cooped about $4-5 \mathrm{~h}$ prior to slaughter. The broilers were slaughtered in a commercial processing plant. Stunning was done using a constant volt- age in-line stunner with voltage of $100 \mathrm{~V}$ and frequency of $50 \mathrm{~Hz}$. Six birds were in the stunner circuit at the same time, the measured average amperage per bird was $120 \mathrm{~mA}$. The birds were exsanguinated unilaterally, bled for $180 \mathrm{~s}$ and scalded at $54{ }^{\circ} \mathrm{C}$ for $180 \mathrm{~s}$ and picked. After evisceration, the broilers were air chilled for 45 min at $0{ }^{\circ} \mathrm{C}$ in circulating air. The end point temperature of breast fillets was $4-6{ }^{\circ} \mathrm{C}$.

Eight different deboning times post mortem were used: $10 \mathrm{~min}, 65 \mathrm{~min}, 2 \mathrm{~h}, 4 \mathrm{~h}, 6 \mathrm{~h}, 8 \mathrm{~h}, 12 \mathrm{~h}$, and $24 \mathrm{~h}$. For the $10 \mathrm{~min}$ group, the breast muscles were excised from carcasses which were taken from the processing line immediately after defeathering (hot-boned). The 65 min samples were removed from carcasses which were taken from the processing line immediately after chilling. The carcasses for the later groups were removed from the processing line after air chilling, and held packed in crushed ice until the time of sampling. The excised breast muscles were placed in plastic bags, transported in ice to the laboratory and were then stored at $4^{\circ} \mathrm{C}$ until the meat quality measurements could be performed on the following day.

One breast muscle from each bird was used for $\mathrm{pH}$ measurement, while the muscle from the opposite side of the same bird was used to determine color, cooking loss and shear force. For $\mathrm{pH}$ determination, duplicate samples were removed from the inner cranial area of the muscle immediately after deboning, and were analyzed according to the iodoacetate method described by Jeacocke (1977). The color, cooking loss and shear force measurements were done at 30-36 h post-mortem. Meat color was determined from the inside surface of the uncooked muscle with a Minolta CR-200 colorimeter using illuminant $\mathrm{D}_{65}$. Muscle samples were then weighed and cooked for $20 \mathrm{~min}$ in $90^{\circ} \mathrm{C}$ steam. The samples were allowed to equilibrate to room temperature and were reweighed. Cooking loss was calculated as a percentage of weight loss from the uncooked muscle weight. Shear force was determined using an Allo-Kramer shear cell in an Instron Universal Testing Machine (Instron, High Wycombe, England). A square shaped sample, 


\section{AGRICULTURAL AND FOOD SCIENCE IN FINLAND}

Vol. 5 (1996): 49-55.

$20 \times 20 \mathrm{~mm}$, was cut from the thickest part of the cranial area of the muscle, such that two sides of square were parallel to the surface muscle fibers. Full scale load was set at $10 \mathrm{~kg}$ and cross head speed was set at $80 \mathrm{~mm} / \mathrm{min}$.

\section{Statistical analysis}

The GLM procedure of SAS /STAT program (SAS Institute 1990) was used to determine time by trial interactions for $\mathrm{pH}$ and shear force data. Since no significant time by trial interactions were found the three trials were combined for further analyses.

The $\mathrm{pH}$ data was analyzed with NLIN procedure of SAS $\%$ STAT program (SAS Institute 1990). A modified Mitscherlich response equation was used to characterize $\mathrm{pH}$ levels of broiler breast muscle as a function of post-mortem time (Ware et al. 1982). The model presented is

$$
y=\beta\left(1+p e^{-\alpha(x-\theta)}\right)
$$

where

$\mathrm{y}=\mathrm{pH}$ level of broiler breast at $\mathrm{x}$ hours postmortem

$\beta=$ the asymptotic minimum value of $\mathrm{pH}$

$\alpha=$ rate of decrease in $\mathrm{pH}$-level

$\theta=$ time $(\mathrm{x})$ when the $\mathrm{pH}$ value is $100 \mathrm{p} \%$ above asymptotic minimum

Shear force gives a objective, quantitative measurement to the tenderness of meat. The variance of shear force changes considerably with time. Therefore ordinary regression or analysis of variance applications may not be suitable for comparing the significance of differences in shear force over time. However, acceptable tenderness is a binary phenomenon from the point of view of the customer: the tenderness of muscle is either acceptable or not. Logit models (Collett 1991) are suitable for analyzing data in the form of proportions. For the purposes of logistic modeling of tenderness, three levels of shear force were tested as high delimiters of acceptable tenderness: $8.0,9.0$ and $11.0 \mathrm{~kg} / \mathrm{g}$. Let $\mathrm{T}$ denote the time post-mortem until deboning (measured in this case on the logarithmic scale) and $\pi(\mathrm{T})$ the probability that a muscle deboned at time $\mathrm{T}$ post-mortem will turn out to be tender. The logit model used for the dependence of the time $\mathrm{T}$ and the probability $\pi(\mathrm{T})$ is

$$
\ln \left(\frac{\pi(T)}{1-\pi(T)}\right)=\gamma+\delta * T
$$

The transformation of the probability $\pi(\mathrm{T})$ on the left side of the equation is called logistic transformation. The probabilities of being tender were thus compared on the logistic scale.

Let $T_{95}$ be the time $T$ that is needed postmortem to assure that $95 \%$ of the muscles are tender in the sense of the definition given above. Hence, in terms of the logit model $\mathrm{T}_{95}$ is the time $\mathrm{T}$ at which $\pi(\mathrm{T})$ equals 0.95 . By substituting this value into the logit model above, $\mathrm{T}_{95}$ can be solved, as soon as $\gamma$ and $\delta$ are known. As these parameters are estimated from experimental data, the time $\mathrm{T}_{95}$ is also subject to experimental error. Based on the standard errors and covariances of the parameter estimates, confidence interval for the time $T_{95}$ was determined by the method of Collett (1991).

The data from the color and cooking loss measurements were analyzed by ANOVA using the GLM procedure of SAS $\%$ STAT program (SAS Institute 1990). The main effects of deboning time, trial, and deboning time by trial interaction were tested using residual error.

\section{Results and discussion}

Post-mortem breast muscle $\mathrm{pH}$ over time is presented in Figure 1. A modified Mitscherlich response equation was applied to estimate when the values reach their ultimate $\mathrm{pH}$ level (level at $24 \mathrm{~h}$ post-mortem). According to the model, $\mathrm{pH}$ did not change after $5.77 \mathrm{~h}$ post-mortem, with an asymptotic $95 \%$ confidence interval of $5.72-5.81 \mathrm{~h}$ post-mortem. The result of this study is different from that of Kijowski et al. (1982), 


\section{AGRICULTURAL AND FOOD SCIENCE IN FINLAND}

Papinaho, P.A. et.al.: Broiler breast fillet deboning time and quality

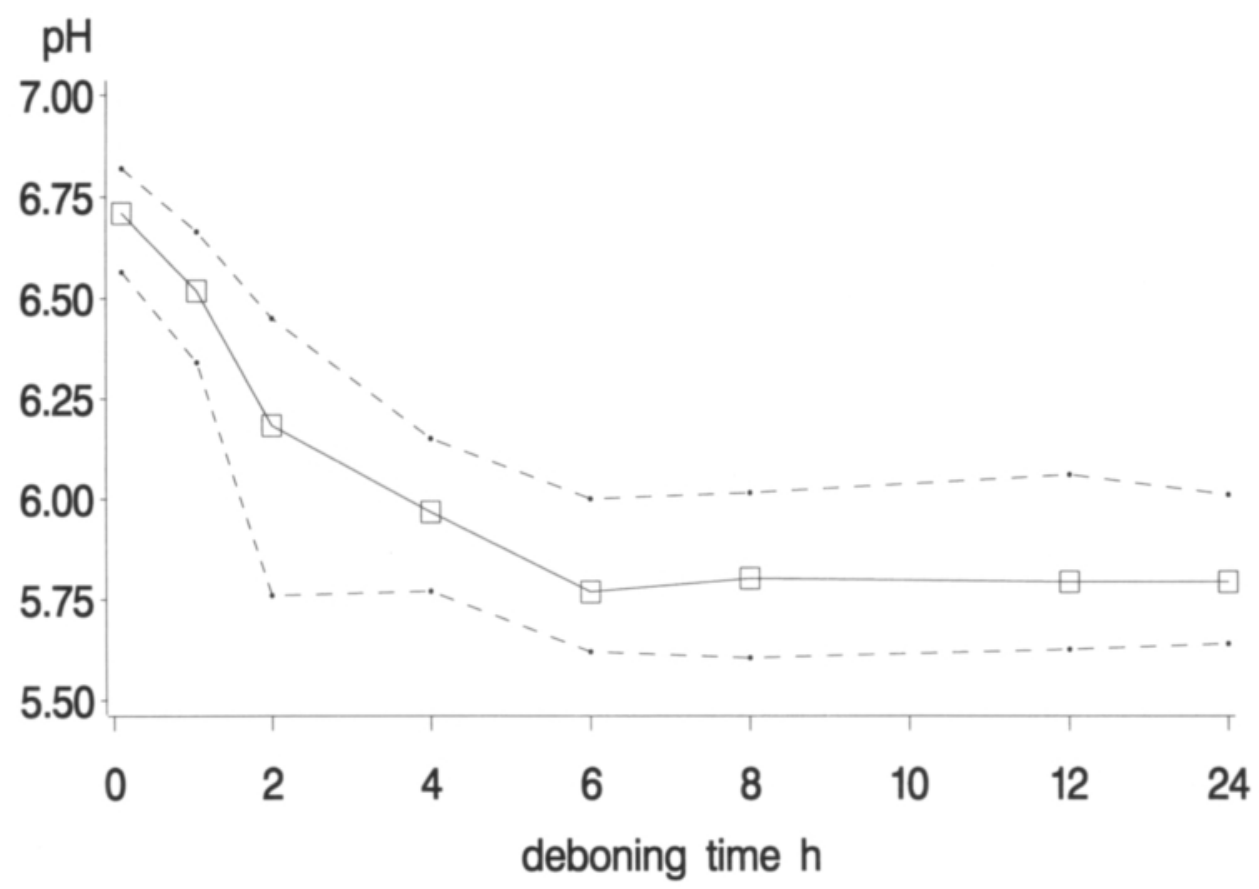

Fig. 1. Breast muscle pH means with $10 \%$ and $90 \%$ fractiles at different times post-mortem.

who reported that $\mathrm{pH}$ did not decrease after $2 \mathrm{~h}$ post-mortem. The first time point for measuring the $\mathrm{pH}$ in their experiment was $15 \mathrm{~min}$ post-mortem, at which time the $\mathrm{pH}$ value was 6.14 . In this study, the $\mathrm{pH}$ was 6.72 at $10 \mathrm{~min}$ post-mortem. However, at $24 \mathrm{~h}$ post-mortem, the $\mathrm{pH}$ values were almost the same: 5.75 for Kijowski et al. (1982) and 5.79 in this study. Smith et al. (1992a) also reported a low early pH level: 6.41 at $15 \mathrm{~min}$ post-mortem. In contrast to Kijowski et al. (1982), but supported by this study, Smith et al. (1992a) found that the $\mathrm{pH}$ at $4 \mathrm{~h}$ was still significantly higher than a value at $24 \mathrm{~h}$ postmortem. These differences may be due to different electrical stunning procedures, as suggested by a previous study (Papinaho and Fletcher 1995), different bird strains, different physiological state of the birds at time of stunning, or different cooling rates of the breast muscles.

Shear force for breast muscles deboned at different times post-mortem is presented in Fig- ure 2. The logistic model was applied to the shear force data three times, using three different levels of shear force as a highest acceptable values: $8.0,9.0$ and $11.0 \mathrm{~kg} / \mathrm{g}$. At each of these levels, the time $\mathrm{T}$ post-mortem before deboning was statistically significant in the logit model $(\mathrm{p}<0.0001)$. The estimate for the time $\mathrm{T}_{95}$ was 5.70 hours with $95 \%$ confidence interval from 3.07 to $10.58 \mathrm{~h}$, when $8.0 \mathrm{~kg} / \mathrm{g}$ was used as a delimiter of acceptable shear force. The results for highest acceptable shear forces of 9.0 and $11.0 \mathrm{~kg} / \mathrm{g}$ were 3.50 and 1.59 respectively. The $95 \%$ confidence intervals for these values were from 2.06 to 5.94 and from 1.10 to 2.28 , respectively. These results indicate that breast muscles should be held intact on broiler carcass up to $10.58 \mathrm{~h}$ post-mortem to guarantee acceptable tenderness, based on a delimiter value of $8.0 \mathrm{~kg} / \mathrm{g}$ as suggested by Simpson and Goodwin (1974). However, if a processor can use a higher delimiter and still meet customer tenderness 


\section{AGRICULTURAL AND FOOD SCIENCE IN FINLAND}

Vol. 5 (1996): 49-55.

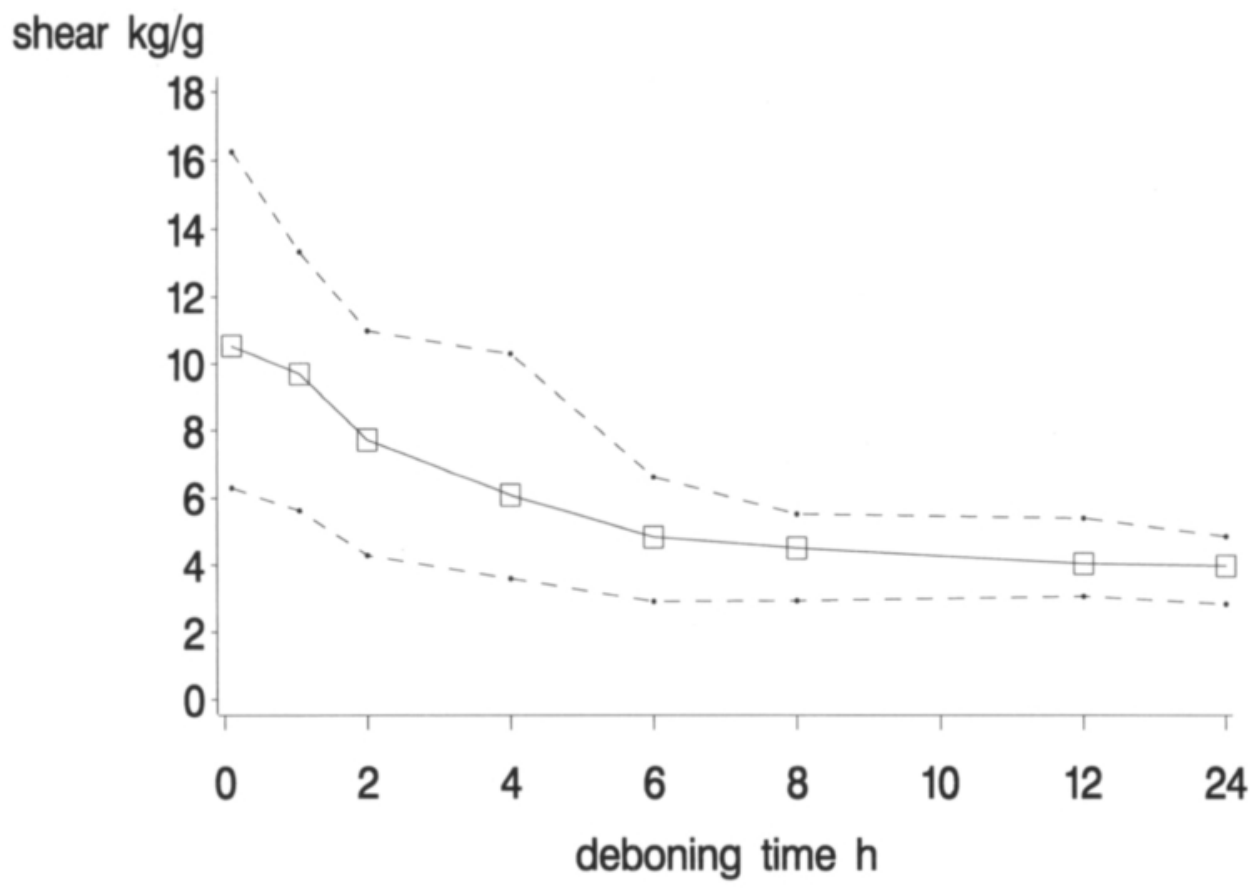

Fig. 2. Allo-Kramer shear force for broiler breast muscles. Lines show means with $10 \%$ and $90 \%$ fractiles for muscles deboned at different times post-mortem.

expectations, deboning times from 2.28 to 5.93 hours may be used.

Lyon et al. (1985) reported that shear force did not significantly $(\mathrm{P}<.05)$ decrease after $4 \mathrm{~h}$ post chilling ( $5 \mathrm{~h}$ post-mortem) and Stewart et al. (1984) found that shear values from broiler breast muscles deboned at $3 \mathrm{~h}$ post-mortem were not significantly different from intact muscles aged for 24 h. Dawson et al. (1987) found significant differences in shear force of broiler breast muscle even for muscles deboned at 8.33 and $24 \mathrm{~h}$ post-mortem. However, he suggested that aging for $3.33 \mathrm{~h}$ would be sufficient for tenderization with no advantage in tenderness gained by deboning at later times up to, and including, $8.33 \mathrm{~h}$. Smith et al. (1992b) reported that shear force values for muscles deboned at 6 $\mathrm{h}$ post-mortem were still significantly higher than $24 \mathrm{~h}$ values. However, all these results were generated in North America using different stunning and chilling methods which may have resulted in faster post-mortem muscle reactions (Papinaho and Fletcher 1995).

Selecting the correct shear force level to correspond to acceptable sensory tenderness values has been the point of interest in some previous research. Simpson and Goodwin (1974) reported that Allo-Kramer shear force values greater than $8.0 \mathrm{~kg} / \mathrm{g}$ corresponded to sensory scores of "slightly tough" to "tough", and values below $8.0 \mathrm{~kg} / \mathrm{g}$ corresponded to "tender" to "very tender". Using more recent techniques to simulate commercial processing conditions for test birds, Lyon and Lyon (1990) reported that shear force values below $6.0 \mathrm{~kg} / \mathrm{g}$ corresponded to "very tender", when values from 6.0 to $8.8 \mathrm{~kg} / \mathrm{g}$ were in the "slightly tender" to "moderately tender" range.

No differences were found in color and cooking loss values within the different deboning times. The average color values were $54.1 \pm .2$ for lightness $\left(\mathrm{L}^{*}\right), 2.0 \pm .1$ for redness $\left(\mathrm{a}^{*}\right)$ and 


\section{AGRICULTURAL AND FOOD SCIENCE IN FINLAND}

Papinaho, P.A. et.al.: Broiler breast fillet deboning time and quality

$4.7 \pm .2$ for yellowness $\left(b^{*}\right)$. The average cooking loss for muscles was $19.8 \pm .2 \%$ of uncooked weight.

On the basis of this study, similar recommendations to those of Goodwin (1984), Shelton (1985) and Stadelman et al. (1988) can be given for broiler breast muscle deboning times, when high voltage stunning and air chilling are used. The shear force data, which were analyzed by the logistic model, suggest that broiler breast fillets should be aged intact on carcasses for 10.58 , 5.94 or $2.28 \mathrm{~h}$ to guarantee that over $95 \%$ of the fillets to reach shear forces of $8.0,9.0$ or 11.0 $\mathrm{kg} / \mathrm{g}$ respectively. Since acceptability of certain meat tenderness may be different in different countries or areas, as well as in different customer groups, the shear force range that is considered as an objective measurement for an acceptable tenderness should be individually determined for each case.

Acknowledgments. This study was supported in part by Ministry of Forestry and Agriculture of Finland and Finnish Food Research Foundation. The authors also wish to thank Dr. Glen Ware for his advice on the statistical modeling of $\mathrm{pH}$, and Ms. Satu Haapala for her technical assistance in processing the samples.

\section{References}

Boyd, L.C. \& Ball, H.R.Jr. 1973. Performance of fresh and aged hot cut broiler meat in chicken rolls. Poultry Science 52: 2000-2001.

Collett, D. 1991. Modelling Binary Data. Chapman and Hall, London. 369 p.

Dawson, P.L., Janky, D.M., Dukes, M.G., Thompson, L.D. \& Woodward, S.A. 1987. Effect of post mortem boning time during simulated commercial processing on the tenderness of the broiler breast meat. Poultry Science 66: 1331-1333.

Dodge, J.W. \& Stadelman, W.J. 1959. Postmortem aging of poultry meat and its effect on the tenderness of breast muscles. Food Technology 13: 81-84.

Goodwin, T.L. 1984. It takes tough discipline to make tender chicken! Broiler Industry 47: 43-44.

Jeacocke, R. E. 1977. Continuous measurement of the $\mathrm{pH}$ of beef muscle in intact beef carcasses. Journal of Food Technology 12: 375-386.

Kijowski, J., Niewiarowiz, A. \& Kujawska-Biernat B. 1982. Biochemical and technological characteristics of hot chicken meat. Journal of Food Technology 17: 553560.

Lyon, C.E., Hamm, D., Thomson, J.E., Hudspeth, J.P., Ayres, J.L. \& Marion J.E. 1983. Effects of hot or cold deboning on functional properties of broiler dark meat and quality of sausage. Poultry Science 62: 965-970.

- \& Lyon, B.G. 1990. The relationship of objective shear values and sensory tests to changes in tenderness of broiler breast meat. Poultry Science 69: 1420-1427.

- , Hamm, D. \& Thomson, J.E. 1985. pH and tenderness of broiler breast meat deboned various times after chilling. Poultry Science 64: 1103-1111.

Papinaho, P.A. \& Fletcher, D.L. 1995. Effect of stunning amperage on broiler breast muscle rigor development and meat quality. Poultry Science 74: 1527-1532.

Pool, M.F., de Fremery, D., Campbell A.A. \& Klose,
A.A. 1959. Poultry tenderness. II. Influence of processing on tenderness of chickens. Food Technology 13: 2529.

SAS Institute. 1990. SAS/STAT User's Guide, Version 6, Fourth Edition. SAS Institute Inc., Cary, N.C.

Sams, A.R. \& Janky, D.M. 1986. The influence of brine chilling on tenderness of hot-boned, chill-boned, and ageboned broiler breast fillets. Poultry Science 65: 13161321.

- , Janky, D.M. \& Woodward, S.A. 1989. Tenderness, and R-value in early harvested broiler breast tissue following post-mortem electrical stimulation. Poultry Science 68: 1232-1235.

Shelton, T. 1985. Broiler industry in the year 2000. Broiler Industry 48: 36-44.

Simpson, M.D. \& Goodwin, T.L. 1974. Comparison between shear values and taste panel scores for predicting tenderness of broilers. Poultry Science 53: 2042-2046. Smith, D.P. , Fletcher, D.L. \& Papa, C.M. 1992a. Postmortem biochemistry of pekin duckling and broiler chicken pectoralis muscle. Poultry Science 71: 1768-1772.

-, Fletcher, D.L. \& Papa, C.M. 1992b. Duckling and chicken processing yields and breast meat tenderness. Poultry Science 71: 197-202.

Stadelman, W. J., Olson, V.M., Shemwell, G.A. \& Pasch, S. 1988. Conversion of live poultry to poultry meat. In: Stadelman W.J. et al. (eds.). Egg and Poultry Meat Processing. Ellis Horwood Ltd., Chichester, England. p. 123-160.

Stewart, M.K., Fletcher, D.L., Hamm, D. \& Thomson, J.E. 1984. The influence of hot boning broiler breast muscle on $\mathrm{pH}$ decline and toughening. Poultry Science 63: 1935-1939.

Ware, G.O., Ohki K. \& Moon, L.C. 1982. The mitscherlich plant growth model for determining critical nutrient deficiency levels. Agronomy Journal 74: 88-91. 


\title{
AGRICULTURAL AND FOOD SCIENCE IN FINLAND
}

Vol. 5 (1996): 49-55.

\section{SELOSTUS}

\section{Korkealla virranvoimakkuudella tainnutettujen broilereiden rintafileen irroitushetken vaikutus lihaksen leikkausvoiman vastukseen, pH:hon, keittohävikkiin ja väriin}

\author{
Petri Papinaho, Hannu Rita ja Daniel L. Fletcher \\ Helsingin yliopisto ja University of Georgia, USA
}

Koesarjan avulla määritettiin broilerin rintafileen $(M$. pectoralis) irroitushetken suhdetta lihan laatuun. Laadun mittareina käytettiin leikkausvoimaa (objektiivinen mureusmääritys), pH:ta, tuoreen lihan väriä ja keittohävikkiä. Kaikki koelinnut prosessoitiin suomalaisessa siipikarjateurastamossa, jossa käytettiin korkeaa tainnutusjännitettä ja -virtaa sekä ilmajäähdytystä. Nämä ovat nykyaikaisen eurooppalaisen siipikarjan prosessointilinjan tyypillisiä piirteitä, ja poikkeavat vastaavasta pohjoisamerikkalaisesta käytännöstä. Muunnetun Mitscherlichin vastemallin avulla analysoiduista $\mathrm{pH}$-tuloksista nähtiin, että $\mathrm{pH}$-arvot saavuttivat lopullisen arvonsa $5,77 \mathrm{~h}$ postmortem, kun
$95 \%$ asymptoottinen luotettavuusväli oli $5,72-5,81 \mathrm{~h}$ postmortem. Leikkausvoimatulokset analysoitiin logistisella mallilla. Niistä voitiin todeta, että broilerin ruhot tulee varastoida kokonaisina vähintään $10,58 \mathrm{~h}$ ennen fileiden irroitusta, jotta voidaan varmistaa, että yli $95 \%$ fileistä alittaa leikkausvoiman $8,0 \mathrm{~kg} / \mathrm{g}$. Koska hyväksyttävä mureustaso vaihtelee maantieteellisestä alueesta ja kuluttajaryhmästä riippuen, sen raja tulee määrittää tapauskohtaisesti vastaamaan markkinoiden vaatimuksia. Rintafileen irroitushetki ei vaikuttanut tuoreen fileen väriin eikä keittohävikkiin. 